\title{
Does Physical Activity Increase Life Expectancy? A Review of the Literature
}

\author{
C. D. Reimers, ${ }^{1}$ G. Knapp, ${ }^{2}$ and A. K. Reimers $^{3}$ \\ ${ }^{1}$ Klinik für Neurologie, Zentralklinik Bad Berka, Robert-Koch-Allee 9, 99438 Bad Berka, Germany \\ ${ }^{2}$ Fakultät Statistik, Technische Universität Dortmund, 44221 Dortmund, Germany \\ ${ }^{3}$ Sportwissenschaft, Universität Konstanz, Universitätsstraße 10, 78457 Konstanz, Germany \\ Correspondence should be addressed to C. D. Reimers, c.d.reimers@t-online.de
}

Received 18 February 2012; Revised 19 March 2012; Accepted 13 April 2012

Academic Editor: Iris Reuter

Copyright ( $) 2012$ C. D. Reimers et al. This is an open access article distributed under the Creative Commons Attribution License, which permits unrestricted use, distribution, and reproduction in any medium, provided the original work is properly cited.

Physical activity reduces many major mortality risk factors including arterial hypertension, diabetes mellitus type 2, dyslipidemia, coronary heart disease, stroke, and cancer. All-cause mortality is decreased by about $30 \%$ to $35 \%$ in physically active as compared to inactive subjects. The purpose of this paper was to synthesize the literature on life expectancy in relation to physical activity. A systematic PubMed search on life expectancy in physically active and inactive individuals was performed. In addition, articles comparing life expectancy of athletes compared to that of nonathletes were reviewed. Results of 13 studies describing eight different cohorts suggest that regular physical activity is associated with an increase of life expectancy by 0.4 to 6.9 years. Eleven studies included confounding risk factors for mortality and revealed an increase in life expectancy by 0.4 to 4.2 years with regular physical activity. Eleven case control studies on life expectancy in former athletes revealed consistently greater life expectancy in aerobic endurance athletes but inconsistent results for other athletes. None of these studies considered confounding risk factors for mortality. In conclusion, while regular physical activity increases life expectancy, it remains unclear if high-intensity sports activities further increase life expectancy.

\section{Introduction}

The most important causes of death in Western industrialized countries are cardio- and cerebrovascular diseases and malignancies. For instance, in Germany in 2008, 68.6\% of all women and $65.9 \%$ of all men died from these diseases. In contrast, the third most frequent cause of death are respiratory diseases which cause less than $10 \%$ of deaths each year (Table 1). Important risk factors for cardio- and cerebrovascular diseases include smoking, arterial hypertension, obesity, diabetes mellitus, and dyslipidemia along with atrial fibrillation for ischemic strokes [1,2].

Regular physical activity reduces the risk of and/or improves many diseases and conditions including arterial hypertension, diabetes mellitus type 2, dyslipidemia, obesity, coronary heart disease, chronic heart failure [3, 4], and chronic obstructive pulmonary disease [4]. In addition, the risk of colon $[3,5]$, breast $[4,5]$, and possibly endometrial, lung, and pancreatic cancer is reduced [5] (Table 2).
The relative risk of death is approximately $20 \%$ to $35 \%$ lower in physically active and fit persons compared to that in inactive and unfit persons $[6,7]$. Physical inactivity represents a major independent risk factor for mortality accounting for up to $10 \%$ of all deaths in the European region [3]. Hence, because a $40 \%$ lower mortality rate corresponds to an approximately 5-year higher life expectancy [8], one would expect an approximately 3.5- to 4.0-year higher life expectancy in physically active persons compared to that in inactive persons.

The purpose of this review was to synthesize the literature on life expectancy in relation to physical activity. Specifically, cohort studies on physically active and inactive subjects were reviewed to detect a possible difference in life expectancy between these subject groups. In addition, cohort studies on athletes and non-athletes were reviewed to detect a possible difference in life expectancy between these subject groups. 
TABLE 1: Number of deaths (percentage of total number of deaths) for the three most frequent causes of death for women and men in Germany in 2008 [9].

\begin{tabular}{lcc}
\hline & $\begin{array}{c}\text { Women (per } \\
100,000 \text { persons/y) }\end{array}$ & $\begin{array}{c}\text { Men (per } \\
100,000 \text { persons/y) }\end{array}$ \\
\hline Total & $467.3(100.0 \%)$ & $720.5(100.0 \%)$ \\
\hline Vascular diseases & $186.4(39.9 \%)$ & $263.6(36.6 \%)$ \\
$\quad$ Coronary heart disease & $61.8(13.2 \%)$ & $117.4(16.3 \%)$ \\
$\quad$ Strokes & $35.8(7.7 \%)$ & $41.6(5.8 \%)$ \\
Malignant tumors & $134.0(28.7 \%)$ & $210.9(29.3 \%)$ \\
Respiratory diseases & $27.7(5.9 \%)$ & $53.3(7.4 \%)$ \\
\hline
\end{tabular}

\section{Method}

To identify all relevant articles about cohort studies investigating the life expectancy of physically active versus inactive persons, a systematic literature search was conducted in the electronic bibliographical database PubMed (http://www.ncbi.nlm.nih.gov/pubmed/). We only searched for English-language peer-reviewed journal articles using the search terms "(life expectancy OR longevity) AND (physical activity OR exercise OR sport)" (last update January 3, 2012). A total of 1,932 articles were found. Using the abstracts and/or titles, forty-one of these articles were identified as cohort studies comparing mortality and/or life expectancy of physically active and inactive persons. However, of these, only 13 articles presented detailed data on life expectancy for both groups.

Subsequently, a search was performed using the terms "(life expectancy OR longevity) AND athlete" to find articles on life expectancy in (former) athletes. Sixty-six articles were found. Additional publications were identified using the search term "(life expectancy OR longevity) AND (physical activity OR exercise OR sport)." Of all these articles, 21 articles investigated mortality and/or life expectancy of (former) athletes. Eleven of these articles presented detailed data on life expectancy of athletes compared to that of a control group.

The remaining life expectancy for physically active and inactive individuals or the difference in remaining life expectancy between the two groups, respectively, were reported in the articles. However, the attained ages of subject groups differed between studies. Because the differences of remaining life expectancies cannot be assumed to be independent from the attained age, we report the results stratified for attained age. Within each stratum of attained age, the results were presented for both sexes.

Only five articles [16-20] reported confidence intervals for the difference in remaining life expectancies between groups. In four articles $[16,18-20]$, a parametric bootstrap procedure was used, and in one publication [17] a nonparametric maximum likelihood approach was used. Consequently, we did not combine the results in a metaanalysis model.

Because a meta-analysis model was not appropriate, all data found in the literature search were reported despite some overlaps between the cohort studies. For instance, Jonker et al. [18] and Nusselder et al. [19] used data from the Framingham Heart Study and Paffenbarger et al. [2124] used data from the Harvard Alumni cohort. While most studies reported results based on multivariate life-table analysis, the studies by Menotti et al. [25] and Pekkanen et al. [26] only reported the results of gained life expectancies for the cohorts based on classical survival analysis. Additionally, the study of Pekkanen et al. [26] reported the survival rate of men aged 40 to 65 years in the following 20 years and not the total life expectancy.

\section{Results}

Thirteen cohort studies presented data on life expectancy in physically active individuals compared to that in physically inactive control subjects (Table 3 ). All studies reported a higher life expectancy in physically active subjects, ranging from 0.43 to 6.9 additional years (mean \pm one standard deviation, men: $2.9 \pm 1.3$ years, women: $3.9 \pm 1.8$ years). Eleven studies considered confounding factors that could affect life expectancy, such as body mass index, blood pressure, diabetes mellitus, dyslipidemia, cardiovascular and lung diseases, cancer, smoking, or alcohol consumption [16$25,27]$. The additional life expectancy in physically active compared to inactive persons in these studies ranged between 0.43 and 4.21 years $(2.7 \pm 1.1$ years $)$. The physically most active groups, included in the estimations of life expectancy, participated in moderate to high leisure time [16, 27-29] or leisure time and all-day activities [17-25].

The median increase of life expectancy of men and women in the eight studies presenting data on both sexes amounted to 3.7 years each. Physical activity during leisure time seems to increase life expectancy more effectively than total physical activity (all-day, professional, or leisure time activity altogether; professional physical activity alone has not been studied): 3.4 added years due to total activities and 4.7 added years (median values) due to leisure time activities in women, 1.9 and 3.9 added years, respectively, in men. The number of studies, however, is too low for a statistical analysis. Furthermore, the description of the amount of physical activity in the active and inactive groups are too heterogeneous for any statistical correlation between the amount of activity and the added years of life.

The eleven case control studies on life expectancy of athletes, mostly elite athletes (Table 4 ), reported a mean life expectancy that was between 5.0 years lower and 8.0 years higher than that of the nonathlete control groups. Aerobic endurance sports resulted on average in a 4.3 to 8.0 years higher life expectancy and team sports activities on average in a 5.0 years lower to about 5 years higher life expectancy compared to that for normal physical activity. Only one study presented data on strength sports and reported a slightly higher life expectancy compared to that for normal physical activity. None of these studies considered any confounding factor that could affect life expectancy. 
TABLe 2: Preventive effects of regular physical activity on major risk factors for cardio- and cerebrovascular diseases and cancer.

\begin{tabular}{lcc}
\hline Author(s) & $\begin{array}{c}\text { Risk factor } \\
\text { Colon cancer }\end{array}$ & $\begin{array}{c}\text { Effect of regular physical activity on } \\
\text { the risk factor in healthy subjects }\end{array}$ \\
\hline $\begin{array}{l}\text { Adami et al. [3], Halle and Schoenberg [10], Warburton et al. [6], } \\
\text { Warburton et al. [11] }\end{array}$ & Breast cancer & Incidence $-20 \%$ to $-50 \%$ \\
Adami et al. [3], Monninkhof et al. [12], Warburton et al. [6] & Type 2 diabetes mellitus & Incidence $-28 \%$ to $-59 \%$ \\
Walker et al. [13], Warburton et al. [11] & Dyslipidemia & HDL cholesterol + $11 \%$ \\
G. A. Kelley and K. S. Kelley [14] & Arterial hypertension & $\begin{array}{l}\text { Systolic and diastolic blood pressure } \\
-3.84 /-2.58 \text { mmHg }\end{array}$ \\
Pedersen and Saltin [4] & Obesity & $\begin{array}{l}\text { Increased chance to maintain body } \\
\text { weight }\end{array}$ \\
Pedersen and Saltin [4] & Stroke & Incidence $-27 \%$ to $-40 \%$ \\
Warburton et al. [11], Reimers et al. [15] &
\end{tabular}

\section{Discussion}

The purpose of this review was to synthesize the literature on life expectancy in relation to physical activity. Being physically active indeed appears to be associated with a higher life expectancy. Samitz et al. [7] as well as Warburton et al. [11] reported a mean reduction of mortality of $31 \%$ to $35 \%$ in persons who participate in regular leisure-time or daily life physical activity compared to that in inactive persons. Assuming a $40 \%$ lower mortality corresponding to a 5-year higher life expectancy [8], regular physical activity should increase mean life expectancy by approximately $(31 \%$ to $35 \%) / 40 \% \times 5$ years or by 3.9 to 4.4 years. Indeed, the few articles that presented data on life expectancy in physically active individuals reported a 0.43 - to 6.9-year higher life expectancy. High-quality studies considering confounding factors that could affect mortality reported a 0.43 - to 4.21years higher life expectancy in physically active compared to inactive persons. The wide range of years added cannot be explained based on the published data.

The studies that standardized extended life estimates for confounding factors $[16,18-25,27]$ virtually calculated a net gain in life expectancy by being physically active. However, the actual increase in life expectancy should be much higher because of favorable effects of physical activity on other risk factors for mortality such as arterial hypertension, glucose and lipid metabolism, coronary heart disease, stroke, or malignancies (Table 1). In fact, nonsmoking, normal weight, and physically fit men live on average 12 years (95\% confidence interval, 8.6 to 14.6 years) longer than smoking, overweight, and physically unfit control subjects [41]. Subjects who never smoked, follow a healthy diet, are adequately physically active, and consume only moderate alcohol have a mean life expectancy that is 11.1 years longer than those who practice none of these healthy life behaviors [42].

The mechanisms underlying the net effect of physical activity are speculative and include reduction of triglyceride and apolipoprotein B concentrations, increase of highdensity lipoproteins and tissue plasminogen activator activity, and reduction of coronary artery calcium resulting in reduced risks of vascular diseases, which carry the strongest mortality risk [43]. In addition, regular physical activity increases the endurance of cells and tissues to oxidative stress, vascularization, and energy metabolism [44].

According to the results of the meta-analysis on allcause mortality in relation to physical activity performed by Samitz et al. [7], vigorous physical activity ( $>6$ metabolic equivalents (MET)) reduces mortality slightly, but this reduction is significantly more pronounced than that for moderate activity (3-6 MET).

A greater life expectancy is not associated with more years of being frail and depending on assistance. In contrary, Nusselder et al. [20] reported a gain of disability-free years of life with a higher life expectancy.

The few data available on life expectancy in athletes who were much more physically active than the average individual are inconclusive. All studies proved an increased life expectancy in endurance athletes ranging between 2.8 to 8.0 added years. This gain is probably higher than that found for persons performing vigorous physical activity in the cohort studies. In team sports and other sports disciplines, life expectancy may fall below or be above that of the control groups. However, data on health behaviors of these athletes other than their physical activity during their active sports career such as smoking, food, and alcohol consumption are not available. Thus, the effect of elite sports activities on life expectancy warrants further investigation.

In summary, as expected from numerous prospective cohort studies on all-cause mortality in physically active and physically inactive persons, estimates on life expectancy in relation to physical activity indicate additional years of life in active subjects: the conservative estimate of the net increase in life expectancy with physical activity is about $2-4$ years but presumably even greater because of the positive influence of physical activity on major risk factors for mortality. 


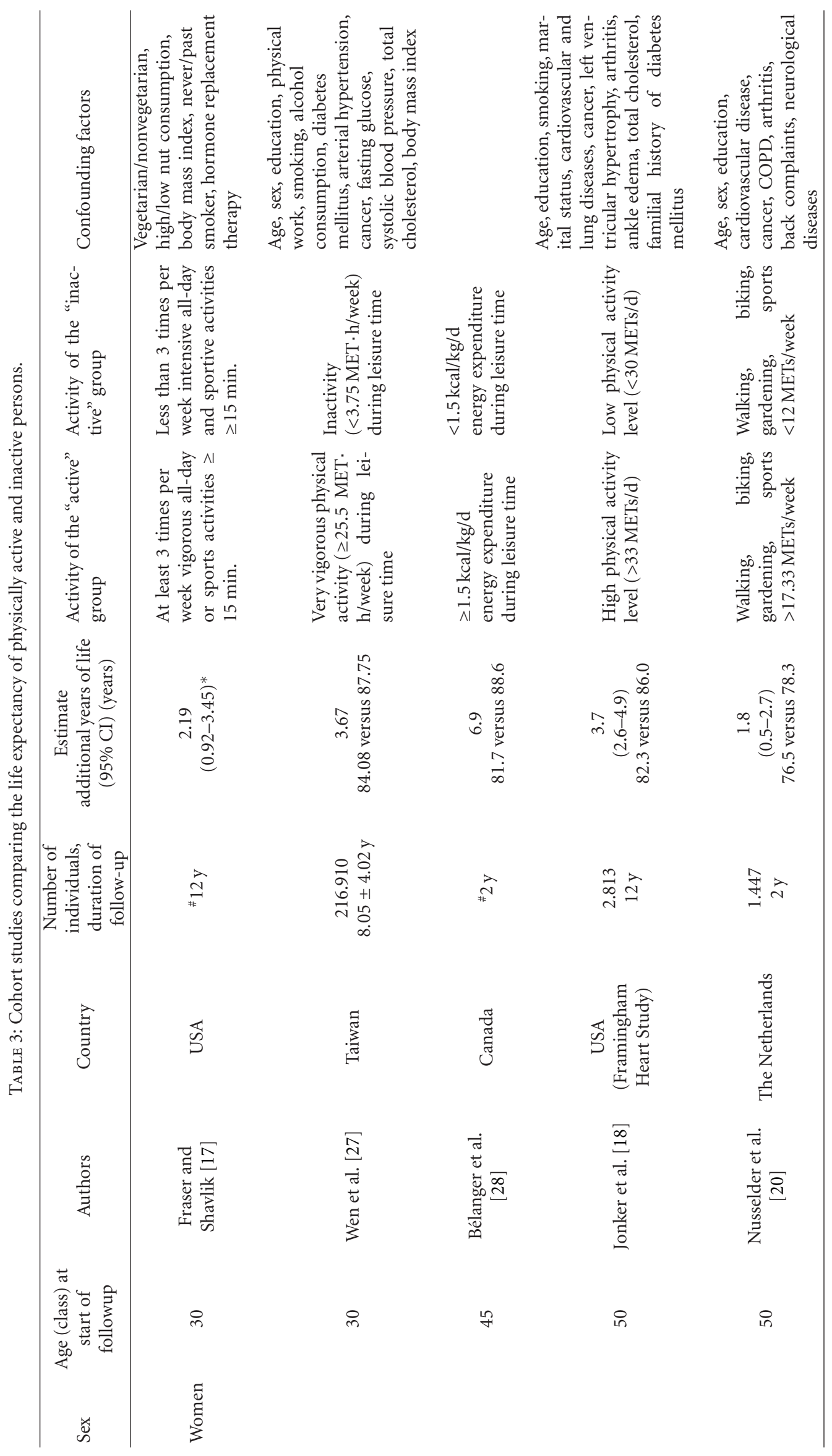




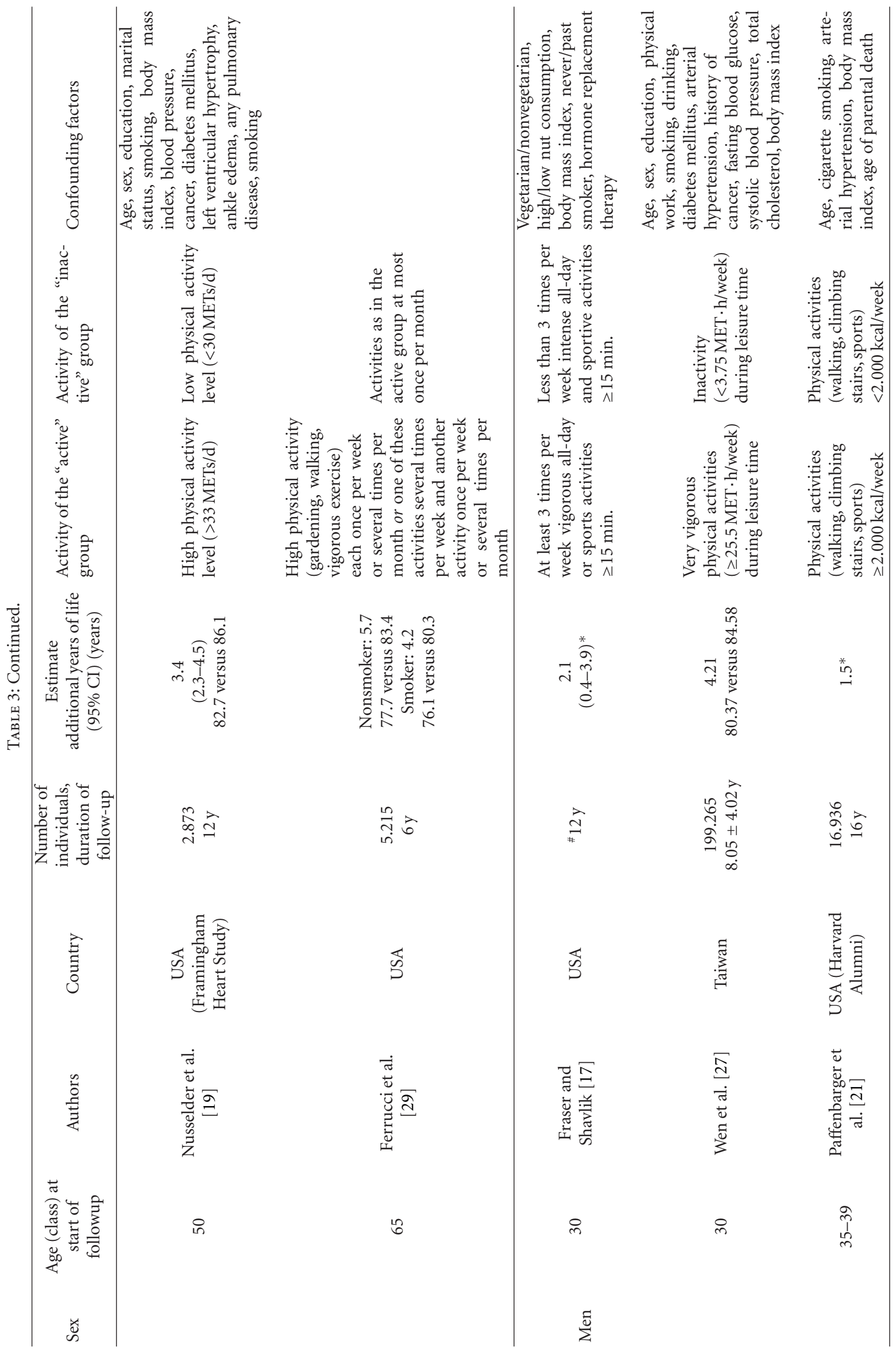




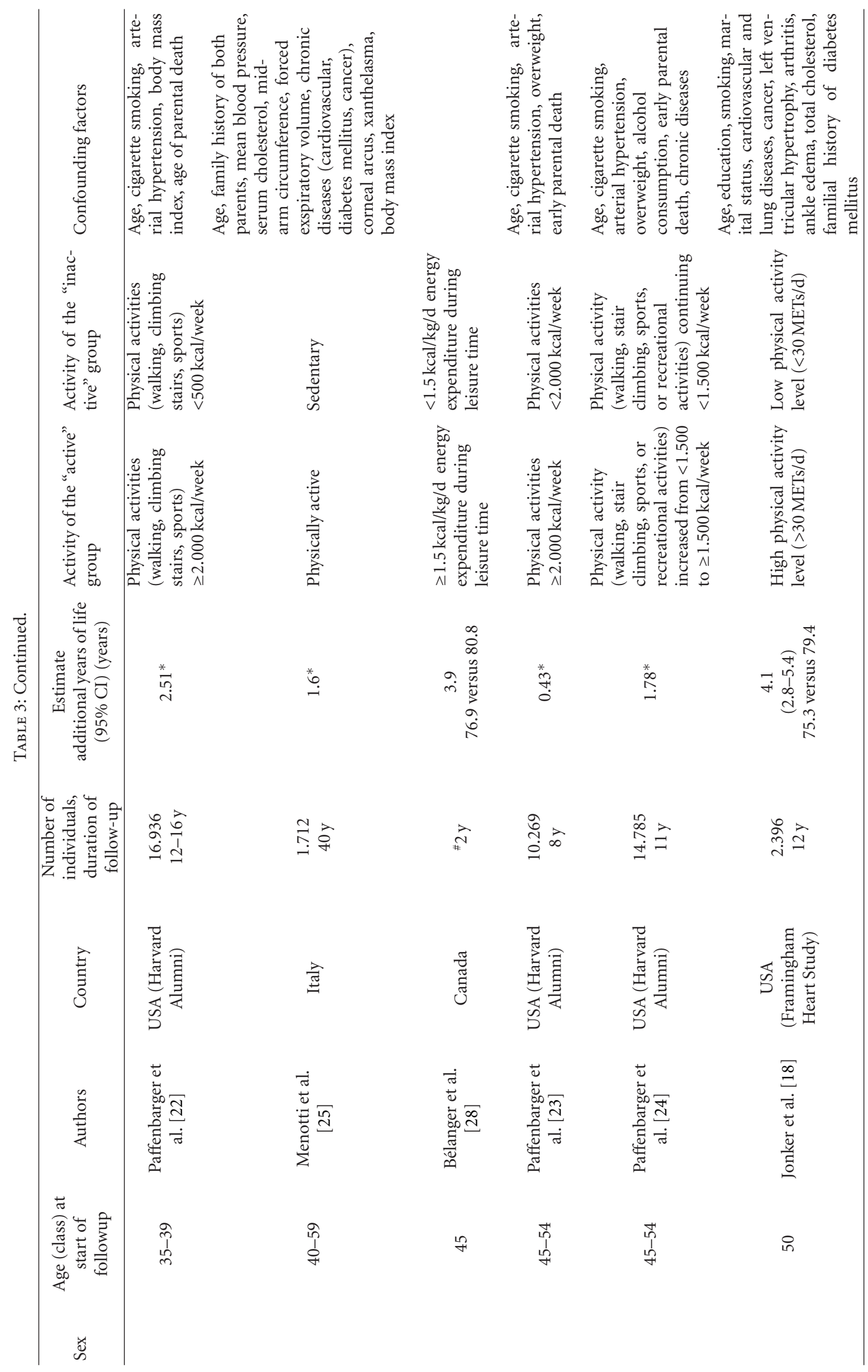




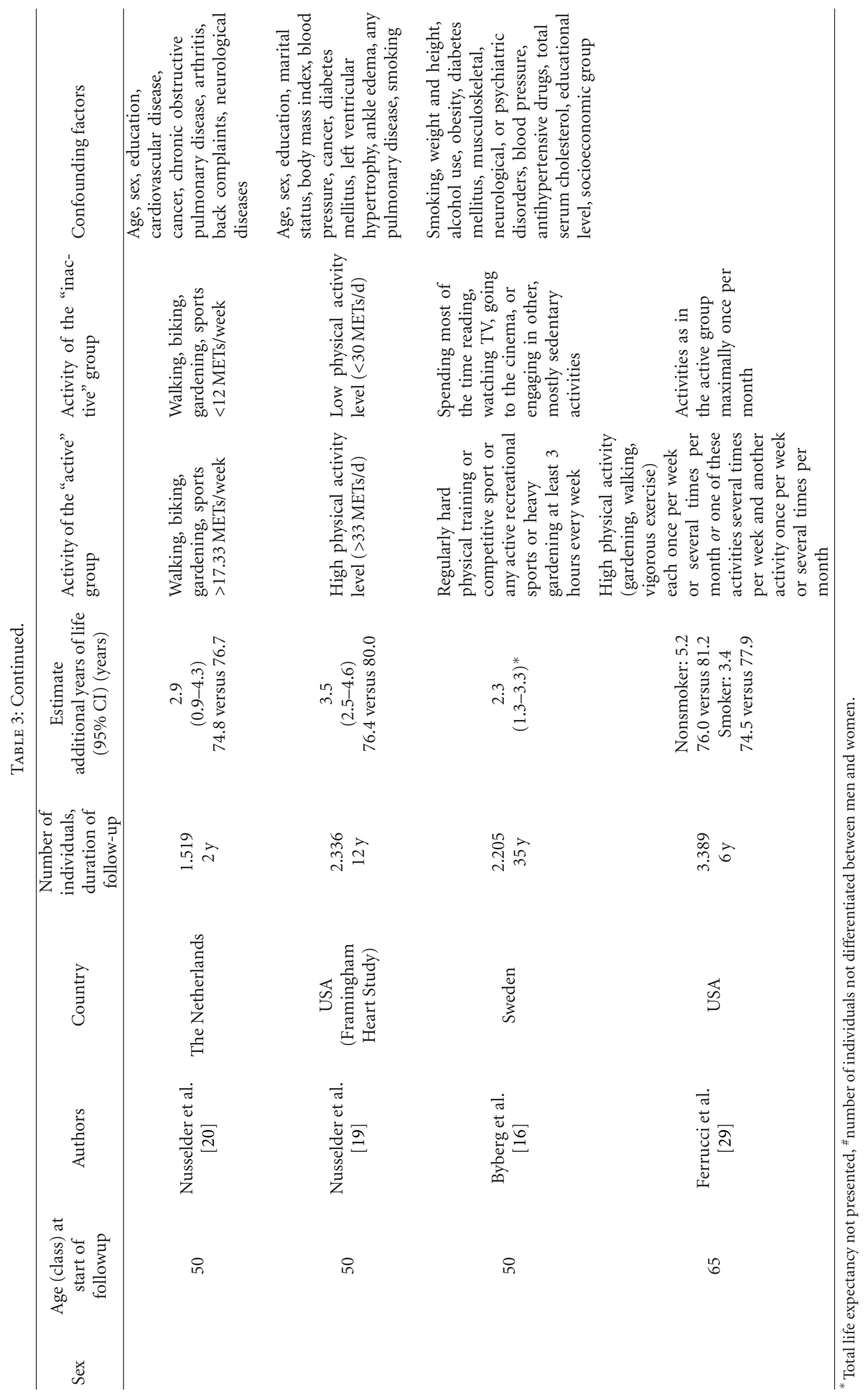


TABLE 4: Case control studies presenting life expectancy of (former) athletes compared to that of control subjects.

\begin{tabular}{|c|c|c|}
\hline Author(s) & Type of sports & $\begin{array}{c}\text { Reduction/increase } \\
\text { in life expectancy } \\
(\mathrm{y})\end{array}$ \\
\hline Prout [30] & $\begin{array}{l}\text { Endurance sports (col- } \\
\text { lege rowers from Har- } \\
\text { vard and Yale) }\end{array}$ & +6.3 \\
\hline Sarna et al. [31] & $\begin{array}{l}\text { Endurance sports (long } \\
\text { distance running, cross- } \\
\text { country skiing) }\end{array}$ & +5.7 \\
\hline $\begin{array}{l}\text { Karvonen [32], } \\
\text { Karvonen et al. } \\
{[33]}\end{array}$ & $\begin{array}{l}\text { Endurance sports (cross- } \\
\text { country skiing) }\end{array}$ & +2.8 to +4.3 \\
\hline $\begin{array}{l}\text { Sanchis-Gomar } \\
\text { et al. [34] }\end{array}$ & $\begin{array}{l}\text { Endurance sports (Tour } \\
\text { de France cyclists) }\end{array}$ & +8.0 \\
\hline $\begin{array}{l}\text { Sarna et al. [31], } \\
\text { Sarna and } \\
\text { Kaprio [35] }\end{array}$ & $\begin{array}{l}\text { Power sports (throwing } \\
\text { sports, wrestling, weight } \\
\text { lifting, boxing) }\end{array}$ & +1.6 \\
\hline $\begin{array}{l}\text { Sarna et al. [31], } \\
\text { Sarna and } \\
\text { Kaprio [35] }\end{array}$ & $\begin{array}{l}\text { Team sports (ice hockey, } \\
\text { soccer, basketball, other } \\
\text { outdoor sports) }\end{array}$ & +4.0 \\
\hline $\begin{array}{l}\text { Abel and Kruger } \\
\text { [36] }\end{array}$ & Team sports (baseball) & -5.0 \\
\hline $\begin{array}{l}\text { Abel and Kruger } \\
\text { [37] }\end{array}$ & Team sports (baseball) & +4 to 5 \\
\hline Kuss et al. [38] & $\begin{array}{lr}\text { Team sports } & \text { (German } \\
\text { international } & \text { soccer } \\
\text { players }) & \\
\end{array}$ & $\begin{array}{c}-1.9 \mathrm{~J} .(+0.6 \text { to } \\
-3.2)\end{array}$ \\
\hline Hudec et al. [39] & $\begin{array}{l}\text { Various } \\
\text { disciplines }\end{array}$ & -0.38 \\
\hline Rook [40] & $\begin{array}{l}\text { Various } \\
\text { disciplines }\end{array}$ & +1.03 \\
\hline
\end{tabular}

\section{Abbreviations}

CI: Confidence interval

COPD: Chronic obstructive pulmanry disease

d: $\quad$ Day

h: $\quad$ Hour(s)

MET: $\quad$ Metabolic equivalent value $(1 \mathrm{MET}=1 \mathrm{kcal}$ per $\mathrm{h}$ per kg of bodyweight)

Min.: Minute(s)

TV: Television

vs: $\quad$ Versus

y: $\quad$ Year(s).

\section{References}

[1] S. E. Straus, S. R. Majumdar, and F. A. McAlister, "New evidence for stroke prevention: scientific review," Journal of the American Medical Association, vol. 288, no. 11, pp. 1388-1395, 2002.

[2] S. Ebrahim, F. Taylor, K. Ward, A. Beswick, M. Burke, and G. Davey Smith, "Multiple risk factor interventions for primary prevention of coronary heart disease," Cochrane Database of Systematic Reviews, vol. 1, Article ID CD001561, 2011.
[3] P. E. Adami, A. Negro, N. Lala, and P. Martelletti, "The role of physical activity in the prevention and treatment of chronic diseases," Clinica Terapeutica, vol. 161, no. 6, pp. 537-541, 2010.

[4] B. K. Pedersen and B. Saltin, "Evidence for prescribing exercise as therapy in chronic disease," Scandinavian Journal of Medicine and Science in Sports, vol. 16, no. 1, pp. 3-63, 2006.

[5] C. M. Ulrich, J. Wiskemann, and K. Steindorf, "Physiologic and molecular mechanisms linking physical activity to cancer risk and progression," Bundesgesundheitsblatt Gesundheitsforschung Gesundheitsschutz, vol. 55, no. 1, pp. 3-9, 2012.

[6] D. E. R. Warburton, C. W. Nicol, and S. S. D. Bredin, "Health benefits of physical activity: the evidence," CMAJ, vol. 174, no. 6, pp. 801-809, 2006.

[7] G. Samitz, M. Egger, and M. Zwahlen, "Domains of physical activity and all-cause mortality: systematic review and doseresponse meta-analysis of cohort studies," International Journal of Epidemiology, vol. 40, no. 5, Article ID dyr112, pp. 13821400, 2011.

[8] B. Farahmand, G. Broman, U. De Faire, D. Vågerö, and A. Ahlbom, "Golf: a game of life and death-reduced mortality in Swedish golf players," Scandinavian Journal of Medicine and Science in Sports, vol. 19, no. 3, pp. 419-424, 2009.

[9] E. Gaber and M. Wildner, "Heft 52-Sterblichkeit, Todesursachen und regionale Unterschiede," in Gesundheitsberichterstattung des Bundes, E. Gaber and T. Ziese, Eds., Robert KochInstitut, Berlin, Germany, 2011.

[10] M. Halle and M. H. Schoenberg, "Physical activity in the prevention and treatment of colorectal carcinoma," Deutsches Ärzteblatt, vol. 106, no. 44, pp. 722-727, 2009.

[11] D. E. R. Warburton, S. Charlesworth, A. Ivey, L. Nettlefold, and S. S. D. Bredin, "A systematic review of the evidence for Canada's Physical Activity Guidelines for Adults," International Journal of Behavioral Nutrition and Physical Activity, vol. 7, article 39, 2010.

[12] E. M. Monninkhof, S. G. Elias, F. A. Vlems et al., "Physical activity and breast cancer: a systematic review," Epidemiology, vol. 18, no. 1, pp. 137-157, 2007.

[13] K. Z. Walker, K. O’Dea, M. Gomez, S. Girgis, and R. Colagiuri, "Diet and exercise in the prevention of diabetes," Journal of Human Nutrition and Dietetics, vol. 23, no. 4, pp. 344-352, 2010.

[14] G. A. Kelley and K. S. Kelley, "Aerobic exercise and HDL2-C: a meta-analysis of randomized controlled trials," Atherosclerosis, vol. 184, no. 1, pp. 207-215, 2006.

[15] C. D. Reimers, G. Knapp, A. K. Reimers, and B. Griewing, "Physical activity and stroke," Aktuelle Neurologie. In press.

[16] L. Byberg, H. Melhus, R. Gedeborg et al., "Total mortality after changes in leisure time physical activity in 50 year old men: 35 Year follow-up of population based cohort," British Journal of Sports Medicine, vol. 43, no. 7, artice 482, 2009.

[17] G. E. Fraser and D. J. Shavlik, "Ten years of life is it a matter of choice?" Archives of Internal Medicine, vol. 161, no. 13, pp. 1645-1652, 2001.

[18] J. T. Jonker, C. De Laet, O. H. Franco, A. Peeters, J. Mackenbach, and W. J. Nusselder, "Physical activity and life expectancy with and without diabetes: life table analysis of the Framingham Heart Study," Diabetes Care, vol. 29, no. 1, pp. 38-43, 2006.

[19] W. J. Nusselder, O. H. Franco, A. Peeters, and J. P. MacKenbach, "Living healthier for longer: comparative effects of three heart-healthy behaviors on life expectancy with and without cardiovascular disease," BMC Public Health, vol. 9, article 487, 2009. 
[20] W. J. Nusselder, C. W. N. Looman, O. H. Franco, A. Peeters, A. S. Slingerland, and J. P. Mackenbach, "The relation between non-occupational physical activity and years lived with and without disability," Journal of Epidemiology and Community Health, vol. 62, no. 9, pp. 823-828, 2008.

[21] R. S. Paffenbarger, R. T. Hyde, C. C. Hsieh, and A. L. Wing, "Physical activity, other life-style patterns, cardiovascular disease and longevity," Acta Medica Scandinavica, vol. 220, no. 711, pp. 85-91, 1986.

[22] R. S. Paffenbarger, R. T. Hyde, A. L. Wing, and C. C. Hsieh, "Physical activity, all-cause mortality, and longevity of college alumni," The New England Journal of Medicine, vol. 314, no. 10, pp. 605-613, 1986.

[23] R. S. Paffenbarger, R. T. Hyde, A. L. Wing, I. M. Lee, D. L. Jung, and J. B. Kampert, "The association of changes in physicalactivity level and other lifestyle characteristics with mortality among men," The New England Journal of Medicine, vol. 328, no. 8, pp. 538-545, 1993.

[24] R. S. Paffenbarger, J. B. Kampert, I. M. Lee, R. T. Hyde, R. W. Leung, and A. L. Wing, "Changes in physical activity and other lifeway patterns influencing longevity," Medicine and Science in Sports and Exercise, vol. 26, no. 7, pp. 857-865, 1994.

[25] A. Menotti, M. Lanti, G. Maiani, and D. Kromhout, "Determinants of longevity and all-cause mortality among middle-aged men. Role of 48 personal characteristics in a 40-year follow-up of Italian Rural Areas in the Seven Countries Study," Aging, vol. 18, no. 5, pp. 394-406, 2006.

[26] J. Pekkanen, B. Marti, and A. Nissinen, "Reduction of premature mortality by high physical activity: a 20-year follow-up of middle-aged Finnish men," The Lancet, vol. 1, no. 8548, pp. 1473-1477, 1987.

[27] C. P. Wen, J. P. M. Wai, M. K. Tsai et al., "Minimum amount of physical activity for reduced mortality and extended life expectancy: a prospective cohort study," The Lancet, vol. 378, no. 9798, pp. 1244-1253, 2011.

[28] A. Bélanger, L. Martel, J. M. Berthelot, and R. Wilkins, "Gender differences in disability-free life expectancy for selected risk factors and chronic conditions in Canada," Journal of Women and Aging, vol. 14, no. 1-2, pp. 61-83, 2002.

[29] L. Ferrucci, G. Izmirlian, S. Leveille et al., "Smoking, physical activity, and active life expectancy," American Journal of Epidemiology, vol. 149, no. 7, pp. 645-653, 1999.

[30] C. Prout, "Life expectancy of college oarsmen," JAMA, vol. 220, no. 13, pp. 1709-1711, 1972.

[31] S. Sarna, T. Sahi, M. Koskenvuo, and J. Kaprio, "Increased life expectancy of world class male athletes," Medicine and Science in Sports and Exercise, vol. 25, no. 2, pp. 237-244, 1993.

[32] M. J. Karvonen, "Endurance sports, longevity, and health," Annals of the New York Academy of Sciences, vol. 301, pp. 653655, 1977.

[33] M. J. Karvonen, H. Klemola, J. Virkajarvi, and A. Kekkonen, "Longevity of endurance skiers," Medicine and Science in Sports and Exercise, vol. 6, no. 1, pp. 49-51, 1974.

[34] F. Sanchis-Gomar, G. Olaso-Gonzalez, D. Corella, M. C. Gomez-Cabrera, and J. Vina, "Increased average longevity among the Tour de France cyclists," International Journal of Sports Medicine, vol. 32, no. 8, pp. 644-647, 2011.

[35] S. Sarna and J. Kaprio, "Life expectancy of former elite athletes," Sports Medicine, vol. 17, no. 3, pp. 149-151, 1994.

[36] E. L. Abel and M. L. Kruger, "The longevity of baseball hall of famers compared to other players," Death Studies, vol. 29, no. 10, pp. 959-963, 2005.
[37] E. L. Abel and M. L. Kruger, "Longevity of major league baseball players," Research in Sports Medicine, vol. 13, no. 1, pp. 1-5, 2005.

[38] O. Kuss, A. Kluttig, and K. H. Greiser, "Longevity of soccer players: an investigation of all German internationals from 1908 to 2006," Scandinavian Journal of Medicine and Science in Sports, vol. 21, no. 6, pp. e260-e265, 2011.

[39] A. Hudec, E. Mahoney, H. J. Montoye, H. Olson, and W. D. van Huss, "Study of the longevity and morbidity of college athletes," JAMA, vol. 162, no. 12, pp. 1132-1134, 1956.

[40] A. ROOK, "An investigation into the longevity of Cambridge sportsmen," British Medical Journal, vol. 1, no. 4865, pp. 773777, 1954.

[41] C. D. Lee, X. Sui, S. P. Hooker, J. R. Hébert, and S. N. Blair, "Combined impact of lifestyle on cancer mortality in men," Annals of Epidemiology, vol. 21, no. 10, pp. 749-754, 2011.

[42] E. S. Ford, G. Zhao, J. Tsai, and C. Li, "Low-Risk lifestyle behaviors and all-cause mortality: findings from the national health and nutrition examination survey III mortality study," American Journal of Public Health, vol. 101, no. 10, pp. 19221929, 2011.

[43] H. M. Ahmed, M. J. Blaha, K. Nasir, J. J. Rivera, and R. S. Blumenthal, "Effects of physical activity on cardiovascular disease," American Journal of Cardiology, vol. 109, no. 2, pp. 288-295, 2012.

[44] Z. Radak, N. Hart, L. Sarga et al., "Exercise plays a preventive role against Alzheimer's disease," Journal of Alzheimer's Disease, vol. 20, no. 3, pp. 777-783, 2010. 


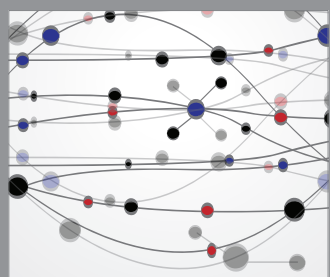

The Scientific World Journal
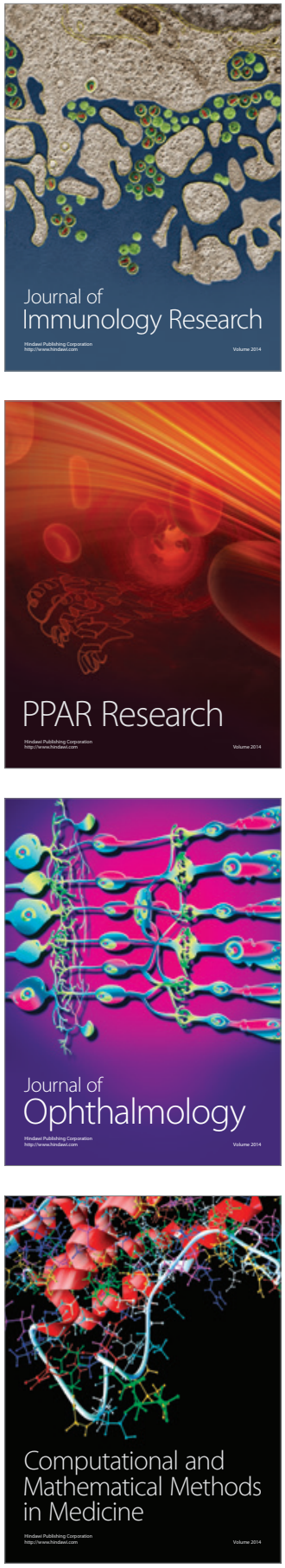

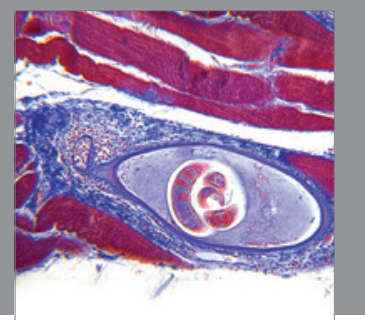

Gastroenterology

Research and Practice
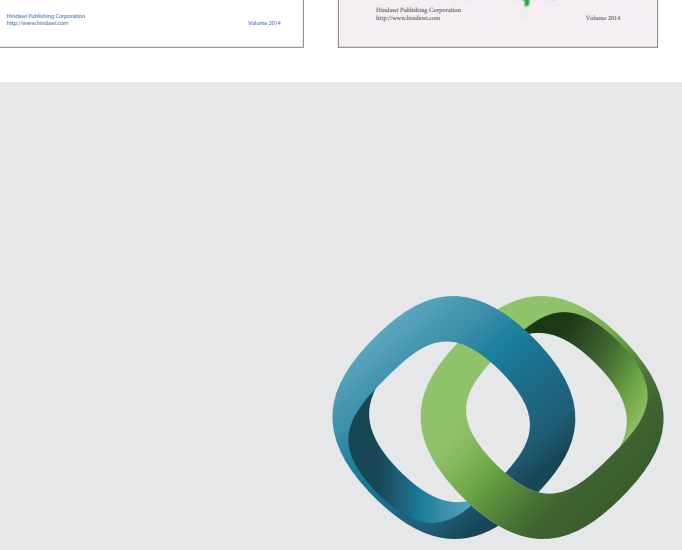

\section{Hindawi}

Submit your manuscripts at

http://www.hindawi.com
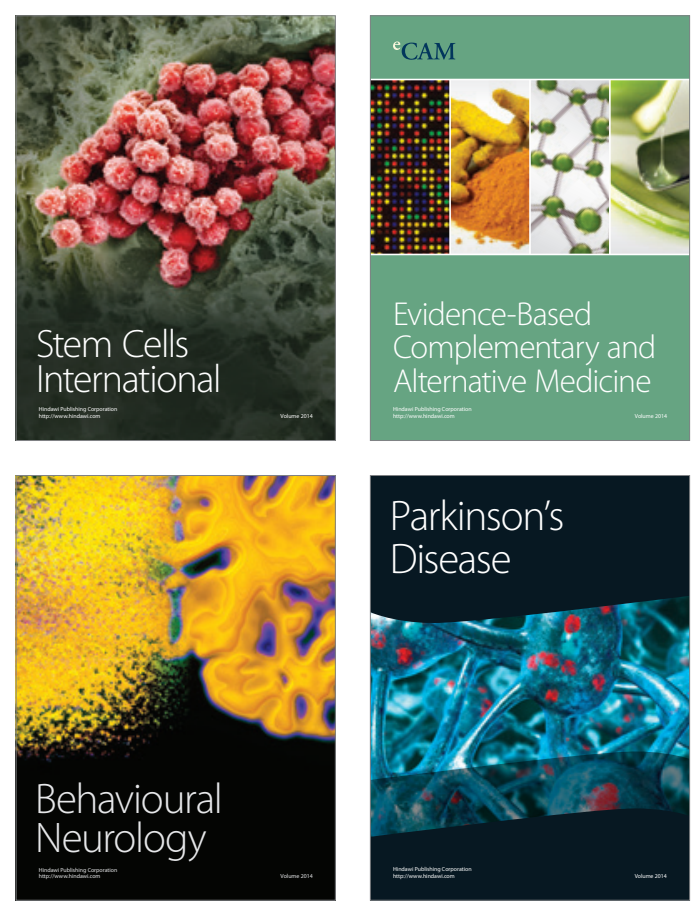

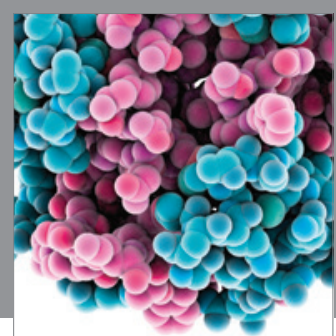

Journal of
Diabetes Research

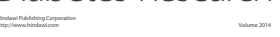

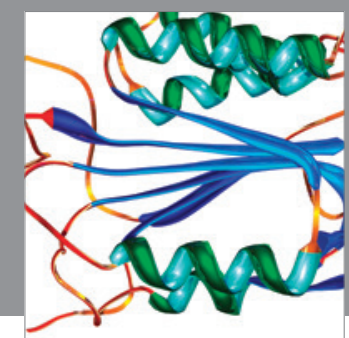

Disease Markers
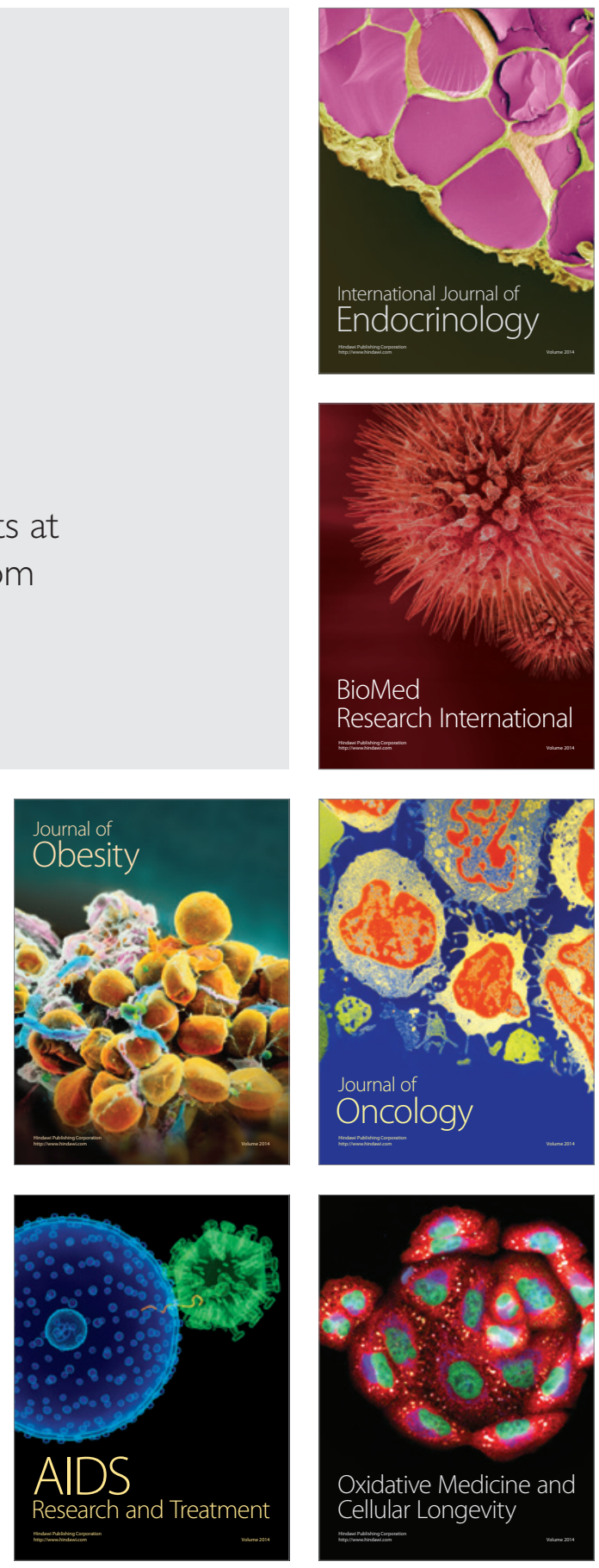